\title{
APPROACHES AND TYPES OF HOUSING PRODUCTION AND LOCAL PRODUCTION AS COMMODITIES
}

\author{
AMORIM, Wagner Vinicius ${ }^{\text {a }}$
}

(a) Phd in Geography, Professor Ceara state University (UECE). http://lattes.cnpq.br/2836208805454597

\section{(*) CORRESPONDING AUTHOR}

Address: UECE, Av. Dr. Silas Munguba, 1700, Campus do Itaperi, CEP: 60714903 - Fortaleza (CE), Brasil. Tel: (+ 55 91) 31019601

E-mail: wagner_g3@yahoo.com.br

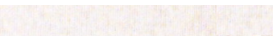

ABSTRACT

We propose a discussion of some approaches and concepts pertaining to the real estate market, real estate and, in more depth, \&quot;real estate production\&quot; and the idea of \&quot;places as commodities\&quot; These last two notions, supported a selected bibliography and a theoretical perspective, bring a broad concept that goes beyond the idea of the real estate market. We understand that the discussion and the elucidation of these notions and / or terms contribute to an understanding of one side of the large-scale production of urban space, as well as shedding light on recent processes relevant to the construction of the city. We demonstrate that perspective from the evolution of the number of establishments of Real Estate Activities, Construction of Buildings and Civil Engineering Works in the cities of Londrina/PR and Maringa/PR, using them as empirical examples and based on the data available from the Annual Relation of Social Information (RAIS), as well as from the evolution of the real estate activity and construction companies.

Keywords: Real estate market. Real estate. Housing production. Production of space.

\section{RESUMO / RESUMEN}

\section{ABORDAGENS E TIPOLOGIAS DA PRODUÇÃO IMOBILIÁRIA E DO LOCAL COMO MER-} CADORIA

Propomos a discussão de algumas abordagens e concepç̃es atinentes ao mercado imobiliário, ao setor imobiliário e, mais detidamente, sobre a "produção imobiliária" e a ideia dos "locais como mercadorias", cujas duas últimas noções, embasadas numa bibliografia selecionada e numa perspectiva teórica crítica, encampam uma concepção ampla, que vai além da noção de mercado imobiliário. Compreendemos que a discussão e a elucidação dessas noções e/ou termos contribuem para com o entendimento de uma das faces da ampla produção do espaço urbano, além de iluminar processos recentes pertinentes à construção da cidade. Demonstraremos essa perspectiva a partir da evolução do número dos estabelecimentos de Atividades Imobiliárias, de Construção de Edifícios e Obras de Engenharia Civil das cidades de Londrina/ PR e Maringá/PR, tomando-as por exemplos empíricos constatados, e baseando-nos nos dados disponibilizados pela Relação Anual de Informações Sociais (RAIS), bem como a partir da evolução das empresas
\end{abstract} de atividades imobiliárias e da construção.

Palavras-chave: Mercado imobiliário; Setor imobiliário; Produção imobiliária; Produção do espaço urbano.

ENFOQUES Y TIPOLOGÍAS DE LA PRODUCCIÓN INMOBILIARIA Y DE LOS LOCALES COMO MERCANCÍAS

Proponemos un análisis de enfoques y conceptos relacionados con el mercado inmobiliario, sector inmobiliario y, más profundamente, acerca de la "producción inmobiliaria" y la noción de los "locales como mercancías", cuyas dos últimas nociones, con el apoyo de una bibliografía seleccionada y una perspectiva teórica crítica, basan un concepto amplio que va más allá de la noción del mercado inmobiliario. Entendemos que la discusión y el esclarecimiento de estas nociones y/o términos contribuyen a la comprensión de una perspectiva de la amplia producción del espacio urbano, así como arrojan luz sobre los procesos recientes de interés para la construcción de la ciudad. Demostraremos esa perspectiva a partir de la evolución del número de los establecimientos de actividades inmobiliarias y establecimientos y de construcción de edificios y obras de ingeniería civil de las ciudades de Londrina/ PR y Maringá/PR tomándolas como ejemplos empíricos constatados, y con base en los datos disponibles en la Relação Anual de Informações Sociais (RAIS) así como de la evolución de las actividades inmobiliarias de las empresas y de la construcción.

Palabras clave: Mercado inmobiliario; Sector inmobiliario; Producción inmobiliaria. 


\section{INTRODUCTION}

Some approaches and some conceptions commonly disclosed in the research and investigations related to the real estate market and to real estate have demonstrated the need to adequately conceptualize the process and the geographic and conceptual scales analyzed. We understand that, before considering the existence of real estate capital itself, which is not be the object of this article, it is necessary to consider "housing production" itself. The process herein is the production of space and the aim of this article is to compare it with the idea of "places as commodities" (LOGAN; MOLOTCH, 1987, 2015), thus seeking a broad conception that goes beyond the notion of the real estate market.

We understand that the discussion and elucidation of these notions and terms contribute to an understanding of one of the aspects of the broad production of urban space, besides shedding light on the recent economic and spatial logic related to the construction of the city. The empirical example used to verify this analytical perspective is the evolution of the number of establishments of real estate activities in general, the development and construction of buildings and civil engineering works of the cities of Londrina / PR and Maringá / PR. For the purpose of this article they are considered only as an immediate empirical locus of the concrete finding of the abstract thought, and not exactly as an empirical locus of a case study, which does not apply to this article's intended proposal. ${ }^{1}$

The article is divided into three parts: in the first, there is a general approach to the market, the real estate market, the real estate sector and the idea of "places as commodities", presenting the main concepts developed in the light of a common theoretical prism, which considers the conflict and not the equilibrium in the market. In the second part, a typology of real estate and construction companies is presented, characterizing them according to the criteria of the National Classification of Economic Activities (CNAE) and the statistical data of the Annual Relation of Social Information (RAIS), as well as using local data collected remotely for the two cities in question. In the final considerations, we seek to align the approaches and conceptualizations under discussion in order to understand how urban space, the product, condition and means of capital appreciation and the reproduction of the social relations of production, appear as the central moment in the reiteration and replacement at higher levels of capital appreciation in real estate production.

\section{APPROACHES AND CONCEPTUALIZATIONS: THE PRODUCTION-CENTERED ANALYSIS}

There is a wealth of literature in Portuguese on the real estate market and the real estate sector, as well as the rich scientific and institutional research developed on the two themes in Brazil, especially in the real estate sector. Many authors have already developed seminal research on these themes, some of whom are covered in this article. Nevertheless, our objective is to offer an understanding of "housing production" according to the theoretical perspective that gave scope to our doctoral thesis (AMORIM, 2015, 2017), without neglecting the contributions coming from other aspects of Urban Geography and economic thought, be they more or less heterodox.

According to the most usual definition used by the economic agents themselves, the real estate market is the real estate sector's market - which, in turn, is often identified as a branch of a secondary sector of the economy - that negotiates land, as well as any construction built on this site. The

(1) We suggest that the reader interested in understanding the economic, political and historical context of the real estate market in the two cities mentioned herein consult our doctoral thesis or book (AMORIM, 2015, 2017), in which we methodologically develop the analysis of these urban spaces and their respective real estate markets, in which we justify our choice to study these two cities, an analysis that is not the specific object of this article, but which empirically grounds the reflection on the real estate market, real estate and housing production. Furthermore, the sources of data used are common to other Brazilian cities, not constituting at this moment and for the purposes of this article, the particularities of the two cities that are the object of the investigation, but the particularities of "places as commodities" and central point of the real estate production process. 
real estate agencies, which broker this business, do it through sale or lease, thus proceeding to the commercialization or administration of the real estate.

According to Topalov (1979: 109), the "real estate sector" is the sector that "[...] produces and circulates real estate goods. This sector includes, of course, the construction industry and also all the other capitalist activities involved in the whole cycle of capital in the sector: real estate development, real estate rentiers, and real estate credit". For Topalov $(1979$, p. 128), the real estate sector has "[...] a very important economic weight in the national product and in global investment. It represents a considerable volume of employment. It uses as inputs products that proceed from many other fields and therefore has a significant stimulus effect on the rest of the economy". Due to the technological and productive characteristics intrinsic to the sector and due to its "weak accumulation" these characteristics are found mainly in the countries of advanced capitalism in the middle of the twentieth century, where a large number of medium and small enterprises and a small number of large enterprises co-exist (Topalov 1979: 129). The author notes that "[...] about the relationships of production in construction: in general, the direct monopolistic implantation is weak. It is even common for the same large companies to remain family-owned, formally independent of financial groups" (TOPALOV, 1979, p.130).

Gottdiener (1997, pp. 217-218) advocates a "property sector," or real estate sector, whose links extend to financial capital, politicians, local groups, political parties, etc., whose interests and conflicts are the guiding thread of spatial changes. According to Gottdiener (1997, pp. 218-219), in the case of the United States in the 1980s, we would be dealing with a special section of capital, organized around land interests in the "secondary circuit" of accumulation, as proposed by Lefebvre (2008: 71). Potentially such interests may be pursued by wealthy capitalists from any of the various fractions of capital, "[...] making the actions associated with the property sector quite complex and often chaotic." (Lefebvre, 2008: p. 71) If there is an organized structure it is due to the combination of fractions of financial, industrial and commercial capital and class and governmental institutions, but without a comprehensive multiscale coordination mechanism and / or between the fractions of capital and the forms of investment that capitalize it (Gottwald, 1997: pp. 219 and 268).

In Botelho (2007, pp. 45-49), we find a definition specific to the Brazilian case. According to the author, the real estate sector is broader and more complex than the construction sector, encompassing it, involving participants from production activities to some tertiary activities: businesspeople, landowners, developers, brokers, consumers, financial agents, producers and dealers of building materials, designers, etc. In short, it is formed by the activities of three national subsectors: the construction industry, the manufacturers of materials and activities related to the tertiary sector, such as commercial real estate activities and administration - development, land subdivisions, the administration of purchase, sale and rental of property.

The real estate sector is an important sector of the Brazilian economy. In 2013, the construction industry and real estate services together corresponded to $13.7 \%$ of the gross added value of the Brazilian gross domestic product (GDP), at basic prices according to classes and activities (CBIC, 2014a).

Figure 1 shows the composition of the construction production chain by percentage share in the total GDP of the chain, elaborated by the Brazilian Chamber of the Construction Industry (CBIC), based on data from the Brazilian Association of the Building Materials Industry (ABRAMAT), in partnership with the Getúlio Vargas Foundation (FGV), for the year 2012. According to the same study, the added value of the construction productive chain was R 328 billion, equivalent to $8.8 \%$ of the Brazilian GDP.

With regard to the articulation of the real estate sector with the financial sector, Fix's doctoral thesis (2011) offers a specific understanding of the constitution of what the author calls the "real estate circuit", which goes from the constitution of the land market in our country after the end of slavery, passing through the National Housing Bank (BNH)/, the Financial Housing System (SFH), the Real Estate Financial System (SFI) and finally the My Home My Life Program (PMCMV). 


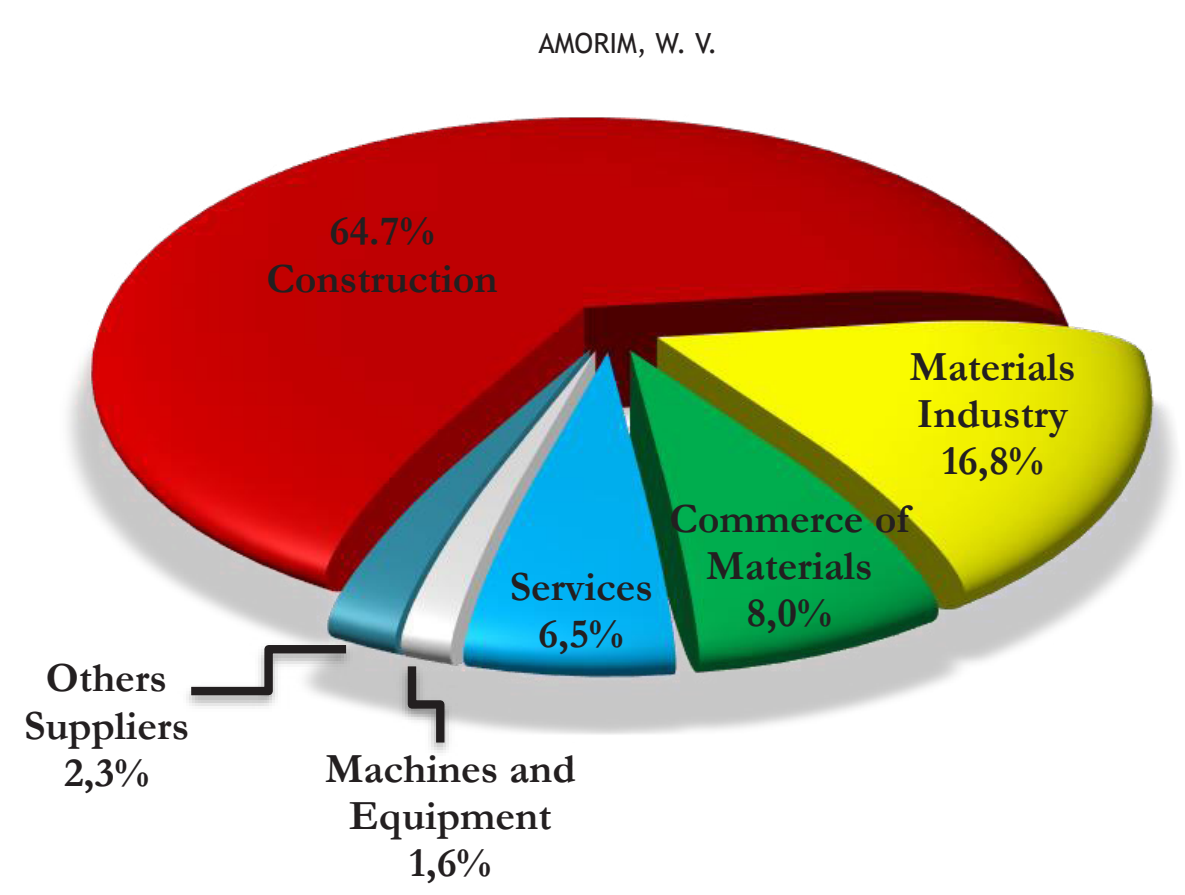

Figure 1 - Brazil. Composition of the construction productive chain by participation in the total GDP of the chain. 2012.

Source: "Profile of the Construction Productive Chain and the Materials and Equipment Industry - 2012". ABRAMAT and FGV Projects. Source Database - CBIC (CBIC, 2014b). Available at: http://www.cbicdados.com.br/ menu/estudos-especificos-da-construcao-civil/productive-chain. Accessed on January 31. 2015.

Historical, circumstantial and contextual issues stand out in this movement and reveal, according to the scope of Fix's research (2011), the financialization of the real estate sector. The transformations that have permeated the formation of the "real estate circuit" in Brazil range from the ownership structure, the financial centralization reserved and exercised by the national elites, the structuring of the public and private funds that feed back into it, the IPO of companies on the São Paulo Stock Exchange (BOVESPA), the supply of real estate credit, the development of new territorial strategies, real estate development, the urban morphology, and construction sites to the form of real estate.

Following these clarifications regarding the real estate sector and its articulations, we return to the theme of the real estate market(s), noting that the scales in which they operate and the institutional arrangements on the actions performed differentiate it from the real estate sector, although understanding them is not possible without the latter.

Even before delving deeper into the discussion of more particular terms, the very conception of marketplace contributes to the problematization of what we intend to discuss here. According to Sandroni (1999: p. 378), the market "[...] means a group of buyers and sellers who are in close enough contact so that exchanges between them affect the buying and selling conditions of the others." "Concretely, it is formed by the set of institutions in which commercial transactions are carried out...". Their formation presupposes the existence of an interchangeable surplus, and a price system arises from the interaction between supply and demand, with supply and demand acting in opposite directions (SANDRONI, 1999, p. 379).

Although classical economists have constructed their theories on the assumption that the market economy is basically formed and / or tends towards equilibrium and perfect competition, the functioning of the market economy has changed profoundly as a result of the expansion and concentration of agents who operate on the supply side and in response to state intervention in the economy, "forming companies, regulating prices, stocks and the money supply..." (SANDRONI, 1999, p.379). Markets can also be classified according to their scope: local, regional, national and global, and among the factors that determine their scope are: "[...] the scale of production, the characteristics of the commodity, the breadth of demand, the degree of trade organization and the stage of economic and social development” (SANDRONI, 1999: p. 379). 
We cannot simply persist with the accessible dictionary definitions if the aim is to radically decompose the terms within the limits and possibilities of this article. Following the aforementioned meaning, we are faced with questions fundamental to understanding the given real estate market: we draw attention to the idea of "proximity" between groups of buyers and sellers, whose perspective from this or that city, from this or that location, from this or that segment and real estate commodity can be variable. It is also noteworthy that it is made up of a set of "institutions" that also differ from the set of institutions of other commodities produced under capitalism. It should be emphasized that these institutions also organize themselves according to the segments of the real estate market, that is, in a heterogeneous manner. The ideas of "surplus" and "competition" are also problematic from the point of view of the real estate market, as well as the structuring of a price system according to these classic premises, given that, in the context of this market, the structuring of prices requires a special treatment, differentiated from that given to the other commodities, the understanding and apprehension of which demand a "spatial look".

Breaking down these attributes with a "spatial gaze", according to Rebelo's definition (2002, p. 304), the real estate market is constituted in a set of market segments, which present the heterogeneity, durability and spatial fixity of the property:

[...] the real estate market can be described as a set of distinct but inter-related submarkets or market segments, containing spaces destined to different types of use, is that they are differentiated by one or more alternative dimensions [...]. These market segments result from the consideration of all the structural attributes and locational characteristics of real estate products by buyers and sellers with some behavioral inelasticity. (REBELO, 2002, p. 304, bold by the author).

Rebelo (2002, p. 304) observes that even if the characteristics of the real estate were identical and the elasticity high, it could produce a competition among potential buyers, corresponding to incomes, expressed as higher prices in some locations than in others. Moreover, if demand is inelastic, "[...] competition between suppliers can lead to the creation of monopolies of income for the various types of space, and the transformation of the real estate 'stock " (REBELO, 2002, p. 305). The author agrees that the price of a real estate product can vary significantly between one market segment and another, and it is necessary to recognize its attributes, the conditions underlying the segments and their structure, which may consist of segments in which supply and demand interact, with the preponderance of the former.

Similarly, "the notion of real estate submarkets as a category of analysis is useful to understand the diversity of the situations contained in the city", found in Smolka (1987, p. 49, emphasis of the author), also shared by Alfonso (2005, p. 163), and even by authors writing for the real estate market, as is the case of Souza (2012) and Cordeiro Filho (2011), assures the existence of distinct segments, of sub-markets within the real estate market, whose segmentation reproduces its incomplete, truncated face, ${ }^{2}$ in which heterogeneous agents command capital movements to the extracts that give them higher yields, continually corroborating certain attributes and locations to the detriment of others, that is, corroborating the "amplitude of the spatial differentiation produced" (SMOLKA, 1987, p. 49) since what happens in one sub-market depends to a large extent on what happens in another.

According to the definition given by Melazzo (1997, p. 37 and 43), the real estate market captures a decision-making environment - certain and uncertain individual and institutional cumulative decisions - in the form of price changes, in the types of real estate and in the locations offered, not limited to the classic expedient of supply and demand, given that the supply is not constrained by

(2) From a heterodox perspective, Abramo (2007: 25) speaks of a “... limited capacity of market coordination ..." which “... requires the use of non-market instruments to ensure the coordination of location decisions [...] ", strictly speaking, the urban policy, indispensable to the configuration of the city's spatial structure. 
fluctuations in the market's demand for the acquisition of land for housing production, for example. For Melazzo (1993, p.59), "the supply is ahead of demand and at any given moment the real estate market is negotiating larger amounts of land than will be immediately occupied." This is because, as new areas are added to the market which, consequently, causes changes in relative prices and accessibility within the city, expectations are generated regarding the possibility of land gains in the future, which feeds the demand for lots of land, not only of those newly developed, but also of those located in areas already occupied in the past, but which have remained empty (MELAZZO 1993: p. 60).

In this way, the problematic is posed of the increase in value of a good that does not derive solely from the constructed product, but of the articulation between it and the historically and socially produced location over time and appropriated in the process of valuation and formation of the prices. Land is a special commodity, which is not the product of individual labor and whose price is not determined by the cost of its production. According to Topalov $(1984, \mathrm{p} .10)$, it can be observed that the price of this commodity cannot be understood where it is offered, in the real estate market taken simply as a relationship between supply and demand, but instead where its price is formed, in the process of appreciation of this capital on this soil. Thus, from the perspective of a market that commercializes "commodities" whose "production" differs from other commodities produced and marketed in the capitalist mode of production, land is a good that becomes a commodity at the same time as it becomes private property, and through this relationship it is possible to charge for its availability, that is, income for its owner.

We are, therefore, faced with a special merchandise, not produced as such, but "organized" as such, as Polanyi (2000, p. 94) observed, a "non-commodity", since "everything that is bought and sold must be produced for sale is emphatically unreal [...]" with regard to land. According to Polanyi (2000: p. 94), "land is just another name for nature, which is not produced by man", its description as a commodity being entirely fictitious, and with the help of this fiction the real markets for this merchandise are organized. Polanyi (2000, p. 94) problematizes the character of the market of the unreal and fictitious 'commodity' land - and of labor and money, in his book The Great Transformation as special commodities under capitalism - noting that "permitting the market mechanism to be the sole leader of the destiny of human beings and their natural environment, and even the arbiter of the quantity and the use of purchasing power, would result in the collapse of society." The radical nature of its conception consists in the defense of the idea that land is a vital part of social life. He emphasizes that "the extreme artificiality of the market economy is rooted in the fact that the production process itself is enjoyed 'in the form of buying and selling"” (POLANYI, 2000, p.95).

Thus, the private property of land as a commodity is constituted, on it and from it modern real estate property is organized and, therefore, its specific market. As a consequence of this right held by owners, businesspeople must have a considerable amount of resources to acquire the land necessary for housing production (BOTELHO, 2007: p. 56), whose process articulates several capitals and fractions of capital, capitalists, owners, businesspeople, laws, institutions etc., formatting the diffuse real estate production and its market.

It is now necessary to discern the terms of "housing production", continuing to break it down, as proposed at the beginning of this article and within its limits and possibilities. Therefore, given the nature of this article, it is imperative to elucidate the terms with which we do our thinking and conduct our research.

A fundamental notion of this research as a whole, "housing production" underlies the conceptual framework of the analytical perspective employed herein. It is fundamental because it contains the category of production. Leaving behind for a moment the defined premises, or rather, as Polanyi (2000) states, "organized" around the idea of the market, it is important to recognize, from Marx (2011), that the relationship of distribution with the production it determines is an issue that is evidently part of the production itself. For Marx, distribution is a product of production, not only 
of historical production in general, but of determined historical production, because the production is seminal. It is also determined unilaterally by other moments, with an interaction between the different moments. It is from production that distribution and property unfold (MARX, 2011, p. 52). Production, distribution, exchange and consumption are not identical, but they are all moments of a totality, differences within a unit.

According to Marx (2011: 53), in Grundrisse:

Production extends both beyond itself in the antithetical determination of production and it overrides the other moments. It is from production that the process always resumes. It is self-evident that exchange and consumption cannot be predominant. In the same way that distribution is the distribution of products. However, as the distribution of the agents of production, it is itself a moment of production. A given production, therefore, determines a consumption, an exchange and a particular distribution, as well as particular relationships of these different moments among themselves. (MARX, 2011, p. 53, our highlights, italics in the original).

In the present case, the determined seminal historical production, which is at the origin of the object, is also unilaterally conditioned by the other moments, interacting with them, differences within a totality and a moment of production because it distributes agents of production, a particular historical production, that after all, historically conditioned a mode of consumption, an exchange, social relations contained in these moments and between them. Thus, we set out what we understand by "housing production" from these brief extracts, whose theoretical and methodological context leads us to inquire into its terms, not in purely in its defense, but to counter them with the hegemonic ideas that restrict debate simply to the supposedly neutral relationship between supply and demand and, above all, to reach a better understanding of the real data and the theme objectified from the chosen analytical scale.

According to Topalov (1984, p. 230), the capital that originates the operation of conversion of rural property into merchandise put on sale in the urban market, or that originates construction operations, the capital of real estate promotion, is autonomous regarding land ownership. However, it is necessary to understand its current multiform, since it is no longer a case of purely autonomous capital, nor a purely absent owner, nor a property as a pure obstacle or phenomenal form whose agents are divorced among themselves in the valuing of space. In our view, it is a question of understanding the ways in which the accumulation of capital in "real estate production" is carried out by means of its relation to landed property and other social relationships derived from it, including the income from land and its metamorphoses.

The truth is that the research on "housing production" has developed under different emphases, sometimes concerning aspects related to real estate, sometimes about the real estate market, or sometimes about promoters, builders, and developers and sometimes about the real estate circuit etc. In spite of these different "views", ours falls on the agents of "housing production" and to the spatial reading of this production process in the cities, aware that this process is not limited to these cities, but is developed geographically, and only a reading from the multiscale perspective allows for its comprehension.

According to Pereira and Hidalgo (2008), "housing production" is a process of geographic transformation, to be understood in a dynamic multi-disciplinary manner and with profound and distinct economic, social and territorial effects, which enable us to understand its causal derivations. They affirm that manufacturing, in the sense of the execution of production, and services constitute the main catalytic components of housing production, especially in Latin American cities (PEREIRA and HIDALGO, 2008). The term imobiliaria, ${ }^{3}$ which refers to the activities of services and activities of construction and manufacturing, cannot be restricted to its etymological definition in Latin immobilis a term that expresses the complete opposite of what actually occurs in the process

(3) 'real estate' is the direct translation of imobiliaria in the original Portuguese version of this article 
of "housing production" in which the only fixed item is the terrain where the activity materializes, although the location itself is also something changeable in time (PEREIRA, HIDALGO, 2008).

According to Sposito (1991, p. 150), "real estate production" means production that:

[...] when it is carried out through the consumption of a property, it allows those who produce it to take ownership of a fraction of the global mass of surplus value, partly as capitalized land rent and partially as profit arising from the construction process of the property, through the capital invested in the means of its production and the exploitation of labor.

"Housing production", according to the author (SPOSITO, 1991, p. 151), consists of "[...] the expression of the reproduction of the capital applied in its construction, having as a condition the access to a fraction of the territory (land) [...]", in a relationship in which land takes on its character of a commodity, through which housing production takes place," [...] guaranteeing to the landowner, the realization of the income from land, capitalized and appropriated through the sale of the property goods, "capturing surplus value as land rent (to the owner) and profit (to the builder / real estate brokers). As an expedient of capitalist production, real estate production places a product on the market with specific production and consumption characteristics, which clearly interfere with the formation of its price, due to the particularity of the real estate commodity, which is different from the other commodities on the market (SPOSITO, 1991, p. 151).

According to Pereira and Hidalgo (2008, p. 7-8), real estate activity "is at the base of the historic construction of the city, a situation that is reflected in the way in which the owners of the land and the investors involved in the construction that takes place on it, have constantly modified the built space of the city". These agents play a complexity of roles in the production and appropriation of space and real estate value, and the understanding of "housing production" runs through the discussion of the role of these agents in the constitution and distribution of the value produced (PEREIRA, 2011, p. 11). The "base" of this "produced value", according to Pereira (2014, p. 8), even at a time of profound financial transformation, continues to be space, whose relevance resides in the monopoly of land ownership emphasizing income from the land in the construction of the city, thus pursuing this as a seminal theoretical challenge to the understanding of the historical particularity of housing production, "which is installed precisely in the capitalist application of the conditions of transformation of value into price in the construction sector" (Pereira, 1988, pp. 12-13). Thus, the market price of real estate's product does not result only from its individual production price but from the differentiated spatial existence of the products that condition it.

In this sense, Pereira (1988, p 112) states:

On the one hand, land as an element of work and, on the other hand, as a material condition for any activity in the function of space and base, presents itself as distinct domains, but, as far as housing production is concerned, they are interwoven in the process of increased value. In real estate production, the appropriation of space through the ownership of land manifests itself both as a precedent and as a consequence of the appropriation of construction work. Due to this double manifestation the increased value of real estate can both presuppose the useful effects created by the general conditions of production and presuppose the value directly developed by the work of constructing a property.

It is the appropriation of land that allows an internal "accommodation" to housing production that occurs between the owners of the land and the capital, which intensifies in the final rise of prices in the real estate market, reflecting social relationships that depend both on the conditions of use of the property - or of its non-use, making the land a reserve of value - and of the local and sectoral conditions of its production (PEREIRA, 1988: 121-122).

In its full form, the private ownership of land, by being transformed into a continent of capital, immobilizes it and becomes an obstacle to its reproduction. However, when it is the object of speculation, in the form of an asset, it is liberated from this character of an economic obstacle, 
although it is still spatially restricted, which allows it value to increase. Examples of this can be found in the unproductive urban voids scattered throughout the city (SPOSITO, 1990). Although these properties are unproductive from the capitalist point of view and from the point of view of urban development, they are sources of accumulation and capture of the socially produced and spatially generated appreciation in the construction of the city.

Following a concrete empirical framework in our analysis, we encounter the necessary approach of the city, specifically from the spatial framework of land ownership as a commodity, the understanding of which is derived from the forms, strategies and actions of local groups and real estate agents. This perspective was developed by Logan and Molotch (1987), for the context of American cities. We believe that it is also valid to explore the way in which places are transformed into commodities in Brazilian society.

Logan and Molotch (1987, p.17) point to the actual and localized market operations, real because the capitalists' interest in locations is objective because, being able to move from one city to another, the primary interest in the profitability of their operations at a given location expresses how relevant locations are to the essential goals of these capitalists. This relevance comes from the exceptional nature contained in each location, which cannot be reproduced in another. They affirm that " every parcel of land is unique in the idiosyncratic access it provides to other parcels and uses, and this quality underscores the specialness of property as a commodity" (LOGAN; MOLOTCH, 1987, p.23). More of the same plot, more of the same product, under occasional identical conditions, cannot be offered on demand. For this reason, the owner of a specific lot controls a whole set of access and spatial relationships made possible by this specific lot, operating with restriction of the competition (LOGAN; MOLOTCH, 1987, p.23-24).

It is this situational and contextual singularity of lots, which is not the product of the inventiveness of an individual entrepreneur or even a group of entrepreneurs in isolation, and their monopolistic access, whether the lot in question is new or old, which renders land practically impervious to the laws of supply and demand. Each product, regardless of its age, is different and unique and each reinforces the monopolistic character and the resulting price structure, although new "levies" on constructions lead the market to a new price level, through the mechanism of established rents (LOGAN, MOLOTCH, 1987, pp.24-25). Because of this "exceptional" character, people pay the "location price", which in fact consists of expected and agreed-upon social expectations, historically and locally agreed, according to the idea that the new price in the future will always be greater than the old price in the present (LOGAN; MOLOTCH, 1987: 27).

Logan and Molotch (1987, p.44) even claim that locations are 'machinations', contingent social constructs. They are defined by their position in a given political, economic, cultural, physical and topographical "organization." "Spatial inequality" is both a cause and a consequence of the differences between the locations and groups, if they use control over this "inequality" to maintain privileges and status in their locations, to the detriment of the smaller localities. This does not take place without the help of locally based class entities who are influential in the decisions, councils and other municipal authorities (LOGAN; MOLOTCH, 1987, p.49).

Based on this perspective, Logan and Molotch (1987, p.49) identified "intersections" of forces that constitute "human settlements," securing locations for "urban fortunes" and "urban fortunes" for locations. In others words, they ensure the the attainment of business interests linked to the future of a locality, linked to the manipulation of locations as exchange values, causing locations to leverage social and economic positions, not without intra and interlocal social conflicts. Business segments are derived from these historic intersections, affiliated with locations and / or movements that seek sites on the basis of the reproduction of their "fortunes".

Next we proceeded to study the segments and business groups identified and selected in the two cities, based on a characterization starting from the typology of the main companies related to housing production and the real estate market. 


\section{IN SEARCH OF A TYPOLOGY OF THE MAIN COMPANIES: REAL ESTATE ACTIVITIES AND THE CONSTRUCTION OF THE CITY}

This characterization is developed according to the criteria of the National Classification of Economic Activities (CNAE), based on the classification of the Annual Report of Social Information (RAIS), and also based on local data collected in fieldwork in the cities of Londrina and Maringá, which will then be examined in the light of empirical data and typological propositions.

The increasing complexity and division of these activities has resulted in several classifications by the CNAE, the most current being the CNAE 2.2., in force since January 1, 2015. According to this present classification (CNAE, 2015), the Construction Section is divided into the Construction of Buildings, Infrastructure Works and Specialized Services for Construction. The Construction of Buildings, which is the Division that interests us, is subdivided, in turn, into the following Groups: Development of Real Estate Enterprises and Construction of Buildings (Figure 2).

The way in which the classification of these activities has changed over time reflects the actual transformations and specializations that have arisen internally in these activities, in addition, of course, to the actual technical changes in the institutional classification. Thus, Figures 1 and 2 show an organizational chart of the most current organization of the two official classifications.

The section called Real Estate Activities contains the Real Estate Activities Division, which is divided into the following Groups: Real Estate Activities of Own Property and Real Estate Activities by Contract or Commission. The first Group, Real Estate Activities of Own Property, is subdivided into the following sub-classes: Purchase and Sale of Own Property, Rent of Own Property and Allotment of Own Land. The Real Estate Activities by Contract or Commission Group is subdivided into the following classes: Intermediation in the Purchase, Sale and Rent of Real Estate and in the Management and Administration of Real Estate. Of these, only the first class is subdivided into two further sub-classes: Brokerage in the Purchase, Sale and Appraisal of Real Estate and Brokerage in Real Estate Rental (Figure 3).

For the analysis of the evolution of the number of companies from the year 2000 onward in the two cities, we adopted the CNAE - 1995 Table as a reference, since the most current versions only provide the disaggregated data from the year 2006, not allowing a complete analysis of the context between the years 2000 and 2013 . From the "Construction" Section we highlight the "Construction" Division, and, from this, the "Construction of Buildings and Civil Engineering Works" Group. From the "Real Estate Activities, Rent and Services Provided to Companies" Section, we highlight the "Real Estate Activities" Division and from the latter the "Real Estate Activities for Third Parties" Group. From the CNAE 1.0 Table of 2001, we highlight the Group "Development, Purchase and Sale of Real Estate", the sequence of which is available for the entire time period, that is, between the years 2000 and 2013.

Tables 1, 2 and 3 and figures 1, 2 and 3 present the number of establishments in the city of Londrina and the city of Maringá according to the classification explained in the previous paragraph. The establishments in the classification "Groups" are arranged, separately, for each year in absolute values. 


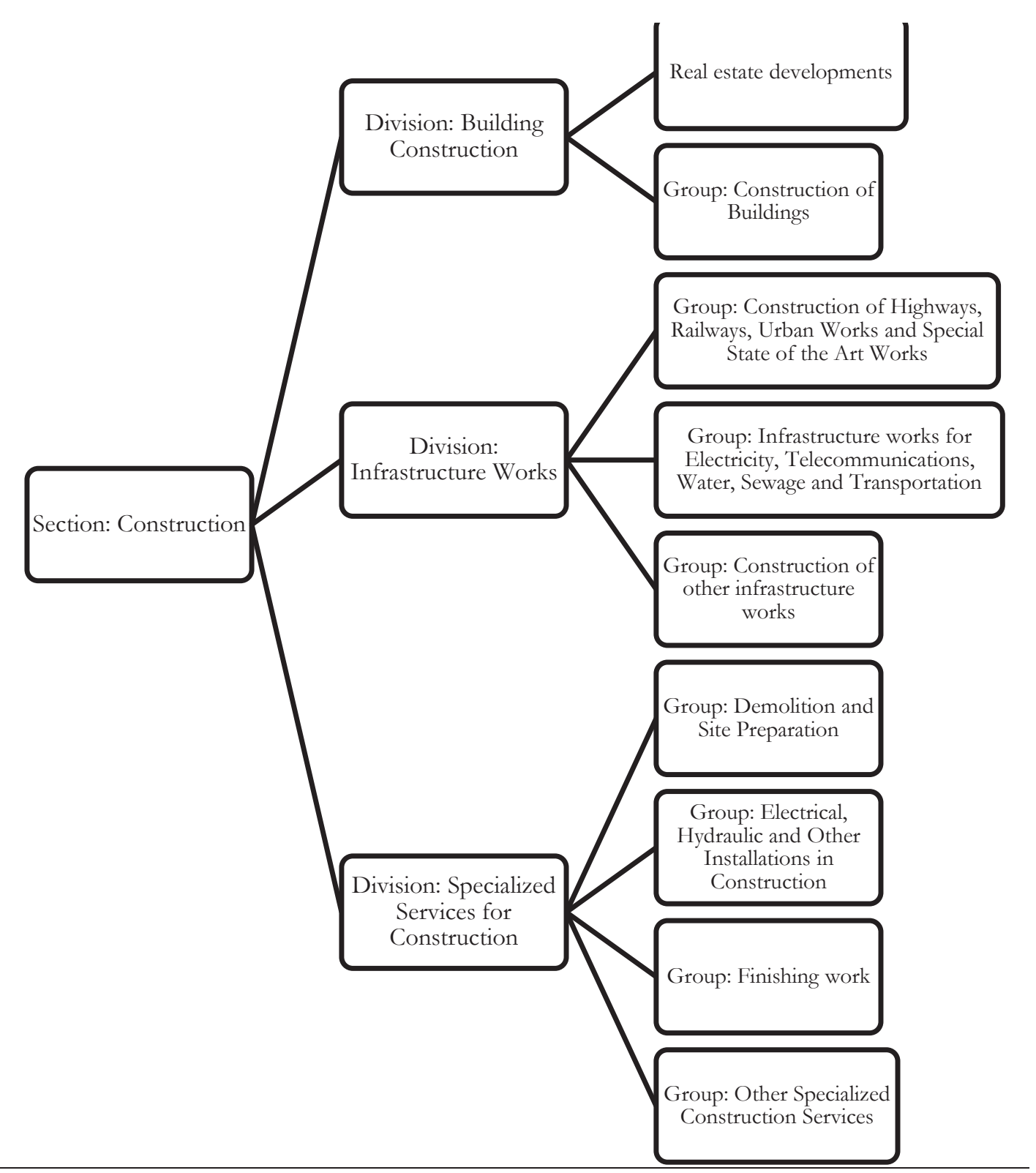

Figure 2 - Organization of the "Construction" Section according to the CNAE 2.2.

Source: National Classification of Economic Activities (CNAE 2.2) (2015)

Organization and preparation: Wagner Vinicius Amorim (2015). 


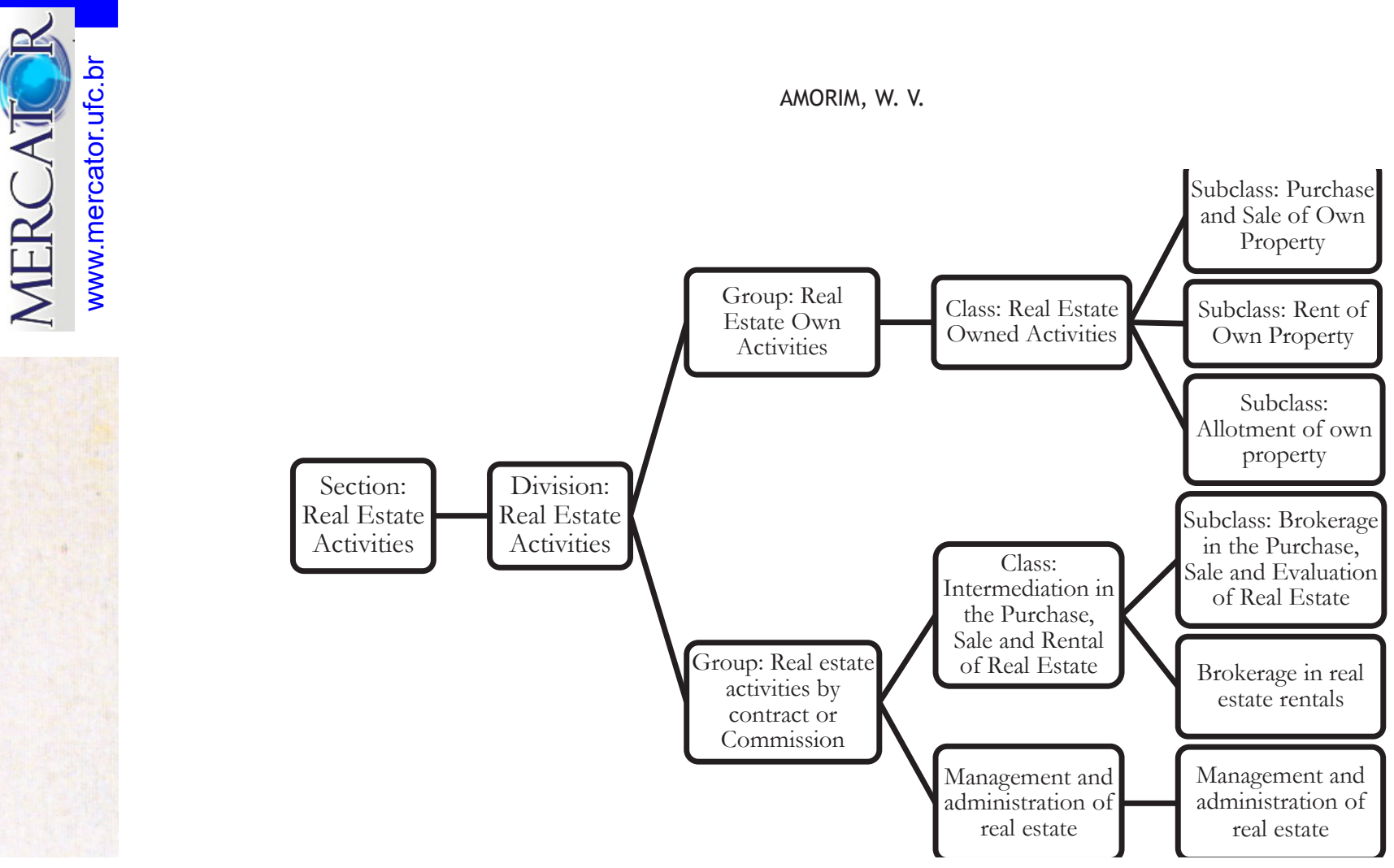

Figure 3 - Organization of the "Real Estate Activities" Section according to the CNAE 2.2.

Source: National Classification of Economic Activities (CNAE 2.2) (2015)

Organization and preparation: Wagner Vinicius Amorim (2015).

The analysis of Table 1 and figure 4 shows that there is an increase in the number of establishments of Real Estate Activities on behalf of Third Parties in both cities. In Londrina, this number increased 80.29\% from 2000 to 2013, while in Maringá there was an increase of around 165\%. Until 2008, the city of Londrina had a more establishments than the city of Maringá, but from 2009 onwards the former exceeded Londrina in the number of establishments. This differentiation is indicative of the real estate dynamics that, in both cities, reveal a rising real estate market, especially in the late 2000s, slightly more pronounced in the city of Maringá.

Table 1 - Londrina and Maringá. Establishments of Real Estate Activities on behalf of Third Parties. 2000-2013.

\begin{tabular}{l|c|c|c|c|c|c|c|c|c|c|c|c|c|c}
\hline \multicolumn{11}{c}{ Real Estate Activities on behalf of Third Parties. (CNAE Group) } \\
\hline & $\mathbf{2 0 0 0}$ & $\mathbf{2 0 0 1}$ & $\mathbf{2 0 0 2}$ & $\mathbf{2 0 0 3}$ & $\mathbf{2 0 0 4}$ & $\mathbf{2 0 0 5}$ & $\mathbf{2 0 0 6}$ & $\mathbf{2 0 0 7}$ & $\mathbf{2 0 0 8}$ & $\mathbf{2 0 0 9}$ & $\mathbf{2 0 1 0}$ & $\mathbf{2 0 1 1}$ & $\mathbf{2 0 1 2}$ & $\mathbf{2 0 1 3}$ \\
\hline Londrina & 56 & 55 & 61 & 57 & 54 & 54 & 55 & 51 & 55 & 64 & 70 & 78 & 91 & 106 \\
\hline Maringá & 43 & 47 & 43 & 44 & 44 & 40 & 49 & 49 & 52 & 65 & 74 & 88 & 101 & 114 \\
\hline
\end{tabular}

* This group contains the following classes: Development of Real Estate on behalf of Third Parties; Administration of Real Estate on behalf of Third Parties.

Source: Annual Relation of Social Information (RAIS). Organization: Wagner Vinicius Amorim (2015). 


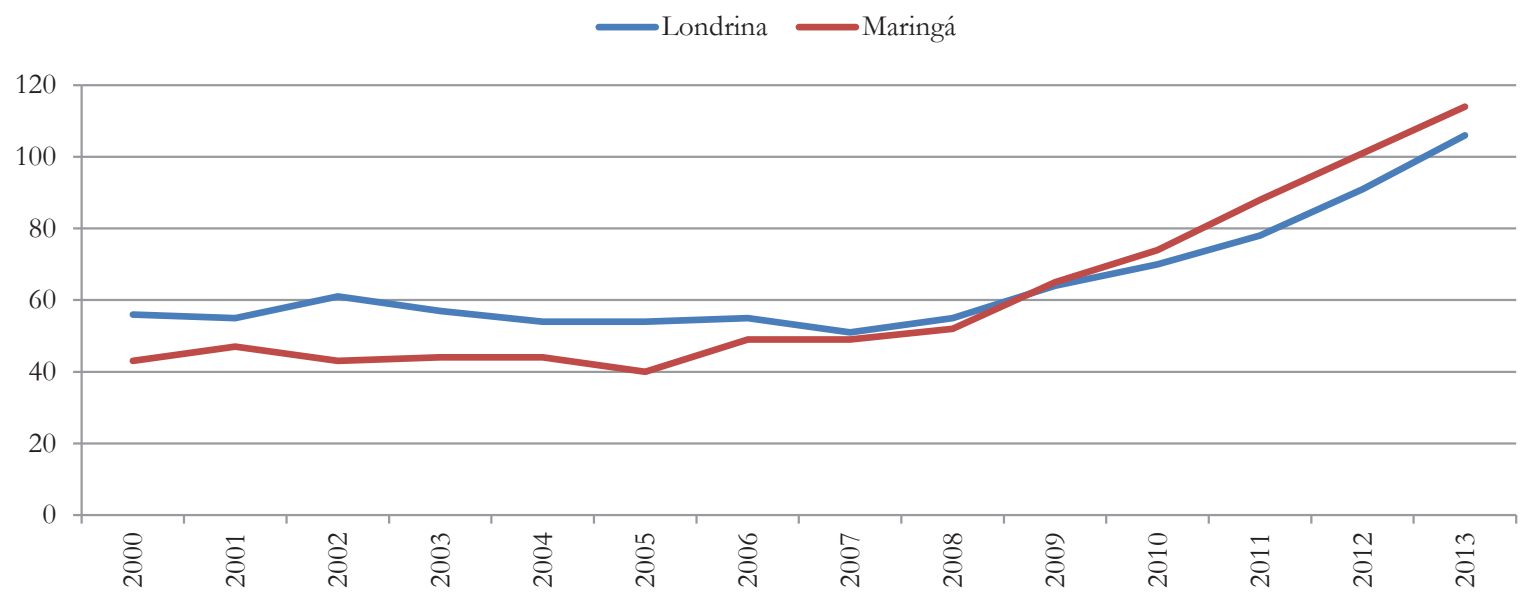

Figure 4 - Londrina and Maringá. Establishments of Real Estate Activities on behalf of Third Parties. 2000-2013.

* This group contains the following classes: Devvelopment of Real Estate on behalf of Third Parties; Administration of Real Estate on behalf of Third Parties.

Source: Annual Relation of Social Information (RAIS). Organization: Wagner Vinicius Amorim (2015).

According to the analysis of Table 2 and figure 5, which show the number of Buildings Construction and Civil Engineering Works in both cities, it is observed that if in the year 2000, Londrina had more establishments of this type than Maringá, in the year 2001 there was a decrease in Londrina and an increase in Maringá. Maringá continued with a greater number of establishments until 2010, losing this position to Londrina in 2011 and 2012, but overtook it again in 2013. In the period in question, the increase in the number of establishments of this type in Maringá was $89.47 \%$ and in Londrina the increase was approximately $33.61 \%$, therefore, less than that in Maringá.

Table 2 - Londrina and Maringá. Establishments of Building Construction and Civil Engineering Works. 2000-2013.

\begin{tabular}{c|c|c|c|c|c|c|c|c|c|c|c|c|c|c}
\hline \multicolumn{11}{c}{ Construction of Buildings and Civil Engineering WorkS } \\
\hline & $\mathbf{2 0 0 0}$ & $\mathbf{2 0 0 1}$ & $\mathbf{2 0 0 2}$ & $\mathbf{2 0 0 3}$ & $\mathbf{2 0 0 4}$ & $\mathbf{2 0 0 5}$ & $\mathbf{2 0 0 6}$ & $\mathbf{2 0 0 7}$ & $\mathbf{2 0 0 8}$ & $\mathbf{2 0 0 9}$ & $\mathbf{2 0 1 0}$ & $\mathbf{2 0 1 1}$ & $\mathbf{2 0 1 2}$ & $\mathbf{2 0 1 3}$ \\
\hline Londrina & 470 & 439 & 453 & 459 & 462 & 503 & 464 & 506 & 563 & 596 & 692 & 746 & 777 & 628 \\
\hline Maringá & 380 & 447 & 516 & 486 & 505 & 507 & 527 & 539 & 613 & 599 & 718 & 705 & 733 & 720 \\
\hline
\end{tabular}

* This group contains the following classes: Buildings (residential, industrial, commercial and service); Road works; Large Structures and State of the Art Works; Urbanization and Landscaping Works; Assembly of Structures; Works of Other Types.

Source: Annual Relation of Social Information (RAIS). Organization: Wagner Vinicius Amorim (2015).

This dynamic of the real estate sector, which reveals itself locally and articulately reveals the mutual influences of a local real estate market, denotes how the local economic dynamics and the orientation of capital towards real estate investments become intrinsically explanatory of real estate dynamics, not only in the understanding of historical-local contexts but also as the central point of the real estate valuation process. 


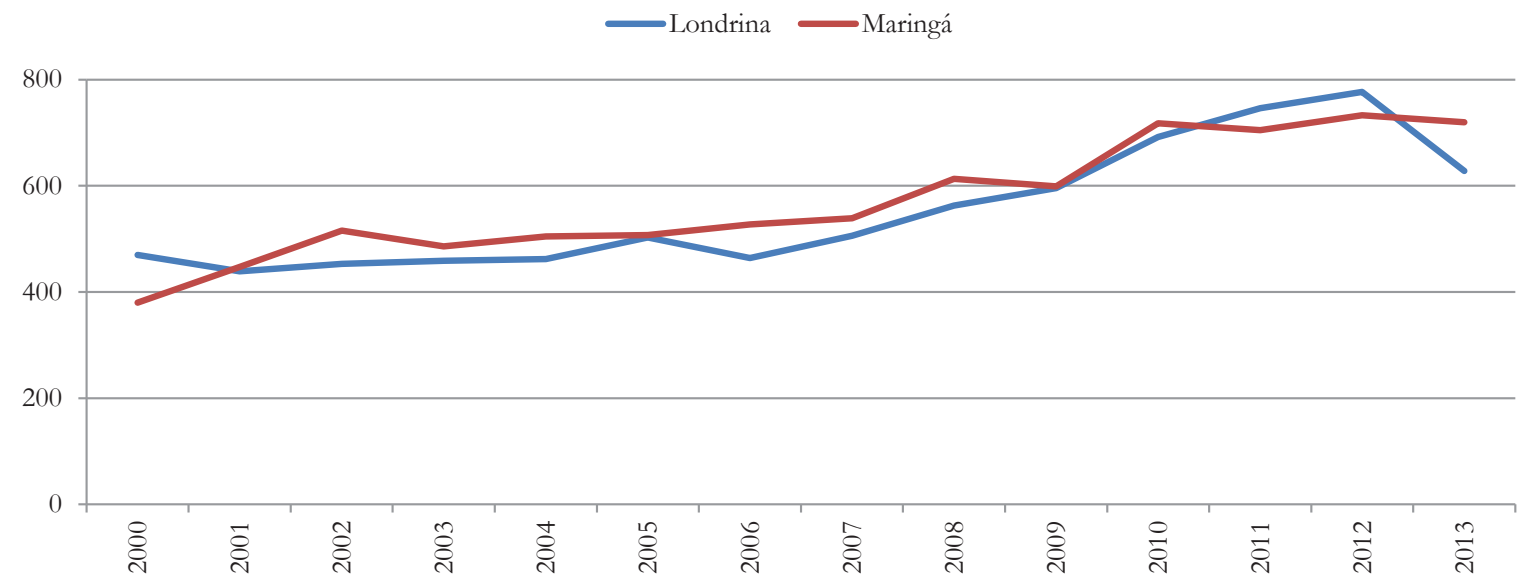

Figure 5 - Londrina and Maringá. Establishments of Building Construction and Civil Engineering Works. 2000-2013.

* This group contains the following classes: Buildings (residential, industrial, commercial and service); Road works; Large Structures and State of the Art Works; Urbanization and Landscaping Works; Assembly of Structures; Works of Other Types.

Source: Annual Report of Social Information (RAIS). Organization: Wagner Vinicius Amorim (2015).

Table 3 and figure 6, in which the numbers of the Mergers and Sale and Purchase establishments are presented, show a constant variation, sometimes with one city in the lead and then the other. In the years of 2000 and 2001, Londrina presented a higher number of establishments of this type. Tied in 2002, the number of establishments in Maringá only exceeded the amount in Londrina in 2003 and 2004. In 2005, they presented the same amount again. In 2006 and 2007 Londrina prevailed. Maringá stood out between 2008 and 2010. Finally, from 2011 to 2013, Londrina presented a higher number than Maringá. The two cities presented high growth rates in the number of these establishments, 496\% in Londrina and 644\% in Maringá.

Table 3 - Londrina and Maringá. Establishments of Merger, Purchase and Sale of Real Estate. 2000-2013.

\begin{tabular}{l|c|c|c|c|c|c|c|c|c|c|c|c|c|c}
\hline \multicolumn{11}{c}{ Merger, Purchase and Sale of Real Estate (CNAE Group) * } \\
\hline & $\mathbf{2 0 0 0}$ & $\mathbf{2 0 0 1}$ & $\mathbf{2 0 0 2}$ & $\mathbf{2 0 0 3}$ & $\mathbf{2 0 0 4}$ & $\mathbf{2 0 0 5}$ & $\mathbf{2 0 0 6}$ & $\mathbf{2 0 0 7}$ & $\mathbf{2 0 0 8}$ & $\mathbf{2 0 0 9}$ & $\mathbf{2 0 1 0}$ & $\mathbf{2 0 1 1}$ & $\mathbf{2 0 1 2}$ & $\mathbf{2 0 1 3}$ \\
\hline Londrina & 25 & 30 & 31 & 34 & 31 & 36 & 48 & 51 & 49 & 58 & 89 & 106 & 127 & 149 \\
\hline Maringá & 18 & 24 & 31 & 37 & 32 & 36 & 46 & 48 & 61 & 85 & 91 & 96 & 105 & 134 \\
\hline
\end{tabular}

* This group includes the following class: Merger, Purchase and Sale of Real Estate (The promotion of real estate projects, that is, the organization of financial, technical and physical resources to carry out of residential developments, sub-division or otherwise, including sale. The purchase and sale of real estate on their own). Source: Annual Relation of Social Information (RAIS).

Organization: Wagner Vinicius Amorim (2015).

It is important to understand the temporality of this variability, considering that the decade of 2000, specifically the second half, was the temporal stage of the historical changes in the institutional structure of the Brazilian real estate and housing market, either through the IPOs on the São Paulo Stock Exchange (BOVESPA) by "real estate companies", ${ }^{4}$ as well as the launch of the PMCMV in 2009. This historical context of the increasing presence of real estate finance and a more directly and indirectly abundant credit, offers a structural explanation of the real estate dynamics common to the two cities regarding the expansion of the number of establishments of Merger, Purchase and Sale of Real Estate.

(4) Generic nomenclature used by the São Paulo Stock Exchange (BOVESPA), to classify the publicly traded real estate companies (MELAZZO, 2013: 6). 
—ondrina —Maringá

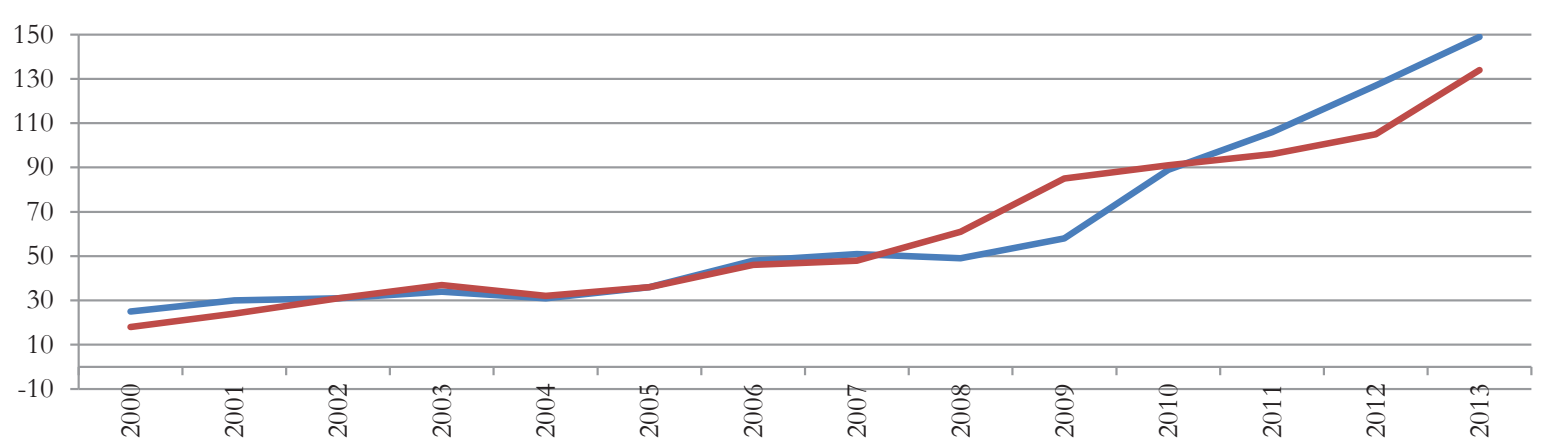

Figure 6 - Londrina and Maringá. Establishments of Merger, Purchase and Sale of Real Estate. 2000-2013.

* This group includes the following class: Merger, Purchase and Sale of Real Estate (The promotion of real estate projects, that is, the organization of financial, technical and physical resources to carry out of residential developments, sub-division or otherwise, including sale. The purchase and sale of real estate on their own).

Source: Annual Report of Social Information (RAIS).

Organization: Wagner Vinicius Amorim (2015).

The analysis of the data set developed so far allows us to understand and examine the dynamism of the market and housing production, either in its local context, as well as in the circumstantial macroeconomic context and the institutional transformations related to real estate financing and housing. These changes took place at the end of the last two decades - the SFI, created in 1997, and the PMCMV, in 2009, as inaugural milestones for a new period of real estate and housing in the country, among the legal frameworks related to the laws created for the expansion and financialization of the real estate sector in the country.

The local context also reveals the structural transformations of the market and real housing production over the last decades. We note this significant change from primary research sources, which are, however, common to most Brazilian cities, and which can be seen as analytical possibilities to be reproduced in other cities, which, in addition, reveal the specificities of location as a commodity and as a capital appreciation orbit in the real estate circuit. The following analytical effort intends to demonstrate contextually and from other sources of data the argument that we have developed in this article, emphasizing the location, without, however, neglecting the previously considered typologies.

The current classification (Figures 1 and 2) corresponds, to a large extent, to company information, which we identified in the cities studied from their listings in online telephone directories, whose search categories are: "Property Managers ", "Construction Companies", "Builders" and "Real Estate Agents". Next we present the analysis of the data collected, in order to develop a reading of the local typology of producing agents and real estate agents.

Based on Telelista and other means of dissemination, we identified a total of 40 real estate managers for the city of Londrina, and 18 for Maringá. With regard to construction companies, we identified 146 for Londrina, and 140 for Maringá. Regarding real estate, we identified 251 companies for the city of Londrina, and 165 for the city of Maringá (Table 4). It is worth noting that this survey is not exhaustive, however it consists of a sample built from the virtual services most used to advertise contacts and real estate in both cities. Following this analysis, the following tables and tables were organized to summarize the data regarding the year of implementation and about the performance of these companies. 
Table 4 - Number of real estate and construction companies listed in the city of Londrina and in the city of Maringá. 2015

\begin{tabular}{c|c|c} 
& Londrina & Maringá \\
\hline Real Estate Management & 40 & 18 \\
\hline Construction companies & 146 & 140 \\
\hline Real Estate Agencies & 251 & 165
\end{tabular}

Tables 5 and 6 show the decades the London and Maringa companies opened, for which we had access to information. In spite of the year of opening for many of them not being available, these are companies with no more than three to four decades of existence. Moreover, unlike the previous decades, after 1970, there was a predominance of legal entities in relation to the construction, development, proposition of new subdivisions and commercialization, which attests to the degree of professionalization and the level of organization of the activity. This fact is due to the creation of Federal Law No. 4,591, dated December 16, 1964, from which there was a great formalization of these activities in Brazilian cities. In addition, the aforementioned law recognized the existence of a specific activity of a concrete capital that differed from the construction companies, real estate development.

In the city of Londrina, the opening of construction and real estate companies was higher in the 1990s and 2000s, as shown in Table 5, due to the opening and dynamization of new appreciation of real estate sectors in the city.

Table 5 - Londrina. Decade of opening of real estate and construction companies.

Decades from 1960 to 2010.

\begin{tabular}{c|c|c|c|c|c|c} 
& Real Estate Management & $\mathbf{\%}$ & $\begin{array}{c}\text { Construction } \\
\text { companies }\end{array}$ & $\mathbf{\%}$ & $\begin{array}{c}\text { Real Estate } \\
\text { Agencies }\end{array}$ & $\%$ \\
\hline $\mathbf{1 9 6 0 s}$ & 1 & 2.5 & 5 & 3.42 & 7 & 2.78 \\
\hline $\mathbf{1 9 7 0 s}$ & 1 & 2.5 & 9 & 6.16 & 20 & 7.96 \\
\hline $\mathbf{1 9 8 0 s}$ & 2 & 5.0 & 11 & 7.53 & 23 & 9.16 \\
\hline $\mathbf{1 9 9 0 s}$ & 2 & 5.0 & 36 & 24.65 & 32 & 12.74 \\
\hline $\mathbf{2 0 0 0 s}$ & 3 & 7.5 & 26 & 17.93 & 31 & $12: 35$ \\
\hline $\mathbf{2 0 1 0 s}$ & - & - & 16 & 10.95 & 17 & 6.77 \\
\hline No information & 31 & 77.5 & 43 & 29.45 & 121 & 48.20 \\
\hline Total & $\mathbf{4 0}$ & $\mathbf{1 0 0 . 0 0}$ & $\mathbf{1 4 6}$ & $\mathbf{1 0 0 . 0 0}$ & $\mathbf{2 5 1}$ & $\mathbf{1 0 0 . 0 0}$
\end{tabular}

Sources: Telelista (http://www.telelistas.net/), Empresas do Brasil (http://empresasdobrasil.com/),

Wooki (https://wooki.com.br/), Jornal Bolsa de Imóveis (http://www.jornalbolsadeimoveis.com.br/) and Websites for each companies.

Organization: Wagner Vinicius Amorim (2015).

In the case of the city of Maringá, the opening of these companies concentrated between the 1980s and 2000s (Table 6), especially in the latter, reflecting the expansion of real estate businesses in the city, based on the most current dynamics of the Brazilian real estate sector and the local real estate market. The local economic context and the macroeconomic situation are present in as much as real estate is a sector that i-mobilizes and re-values resources coming from different capitals in 
the local orbits of the real estate market, that is, it articulates space and market, restoring the levels of capital appreciation insofar as it triggers the production of urban space in the wake of real estate production.

Table 6 - Maringá. Decade of opening of real estate and construction companies.

Decades from 1960 to 2010.

\begin{tabular}{c|c|c|c|c|c|c} 
& Real Estate Management & $\mathbf{\%}$ & $\begin{array}{c}\text { Construction } \\
\text { companies }\end{array}$ & $\mathbf{\%}$ & $\begin{array}{c}\text { Real Estate } \\
\text { Agencies }\end{array}$ & \begin{tabular}{c}
$\%$ \\
\hline $\mathbf{1 9 6 0 s}$
\end{tabular} \\
\hline $\mathbf{1 9 7 0 s}$ & 1 & 5.55 & - & & - & \\
\hline $\mathbf{1 9 8 0 s}$ & 1 & 5.55 & 9 & 6.42 & 5 & 3.03 \\
\hline $\mathbf{1 9 9 0 s}$ & 3 & 5.55 & 27 & 19.28 & 22 & 13.33 \\
\hline $\mathbf{2 0 0 0 s}$ & 5 & 16.66 & 25 & 17,85 & 28 & 16.96 \\
\hline $\mathbf{2 0 1 0 s}$ & - & 27.77 & 38 & 27.14 & 43 & 26.06 \\
\hline No information & 7 & - & 13 & 9.28 & 20 & 12.12 \\
\hline Total & $\mathbf{1 8}$ & 38.88 & 28 & 20.00 & 47 & 28.48 \\
\hline
\end{tabular}

Sources: Telelista (http://www.telelistas.net/), Empresas do Brasil (http://empresasdobrasil.com/), Wooki (https:// wooki.com.br/), Jornal Bolsa de Imóveis (http://www.jornalbolsadeimoveis.com.br/) and Websites for each companies. Organization: Wagner Vinicius Amorim (2015).

With regard to attributions, the segmentation within the branch of activity and the specializations of construction companies and developers in Londrina and Maringa, the profile we have built enables us to point out the performance of the following activities:

1. Construction companies of residences, with construction companies that are more dedicated to buildings and those that are more dedicated to "closed residential spaces" and open lots;

2. Commercial, corporate, educational, industrial, agro-industrial, hospital, medical clinics, bank branches, hotels and tourist centers, shopping malls, gas stations, super and hypermarkets etc.;

3. Construction companies focused on major public works and infrastructure - earthworks, asphalt paving, road maintenance, sanitation, housing projects, management and execution of extensions and constructions of energy substations, engineering and highway concessionaires - engineering companies focused on the activities of repairs, maintenance, structural reinforcements and reforms, consultancies and expert technical reports etc.

Regarding the attributions, the segmentation within the branch of activity and the specializations of the London and Maringa real estate agents, the profile allows us to point out the following activities performed according to companies that act as:

1. Real estate, real estate developer, developer and real estate manager;

2. Own property manager;

3. Administrator of real estate of third parties;

4. Real estate and construction company;

5. Intermediation in the sale of new real estate, with local sales shifts, and in the intermediation of real estate of third parties;

6. Consulting and real estate advice;

7. Real estate companies founded exclusively for a particular enterprise, possibly real estate and land developer;

8. Intermediation in the purchase / sale / leasing of urban and rural properties; 
9. Formation of groups for condominiums at cost price - more specifically some real estate and construction companies in the city of Maringá.

\section{FINAL CONSIDERATIONS}

This article intends to contribute towards the understanding of different faces of local housing production, analyzing the performance of developers, construction companies, real estate developers, consultants and local real estate managers. To do so, first it was necessary to go through the main approaches and conceptualizations of the real estate market, the real estate sector, and "housing production" and, finally, to return to the idea of "places as commodities" by Logan and Molotch (1987). The characterization of the agents was executed so that we could undertake analytical efforts in search of a typology of the main companies, arriving at the real estate activities and the construction of the city.

The companies associated with real estate businesses are complex and operate through a diversity of strategies, expedients and actions that makes it difficult or even impossible to understand them and fit them into a single typology. In addition, we question the common understanding of how the real estate market is composed and structured, how it is organized and how it can be defined, if from the point of view of a market, as Abramo (2001) asserts, whose proposal of " urban convention "is the arena through which the real estate product circulates, is negotiated, bought and sold, or if, on the contrary, it contrasts with a specific and finished market organization, whose conflicts, asymmetries, contradictions, unfinished regulation, modes of organization and operation differentiate it from what, from the capitalist point of view, is meant by "full market". In approaching concepts and typologies of the real estate market, the real estate sector, housing production and "places as commodities" our intention is to contribute with a contextual reading of housing production. The development of a typological analysis of the major companies involved in real estate and construction activities in and of the city was carried out to undertake analytical efforts in search of a comprehensive reading of the role of this fraction of capital in cities.

It means, therefore, understanding the production of urban space based on the performance of these agents, understanding how the segmentation of and in the real estate market - expressed in the dynamics of urban land prices - is linked to social-spatial segmentation that can be represented through socioeconomic indicators, such as income. Without reducing them to themselves, aware that they are conditioned by more complex elements, these segmentations are operationalized by private and public agents and, in the case of the former, such segmentations position many of their decisions that, when agreed and articulated between a 'local group' of agents, rearrange the urban structure and impose a 'spatial matrix of real estate appreciation' on the city and city dwellers.

Although the word matrix, taken here as metaphor, carries a rigid sense, like its use in the "hard sciences", we understand that the agents of the real estate market and housing production act in the sense that the management of the urban spatial structure is as manipulated and controllable as a physical variable contained in a system. If it were not for the asymmetries, diversities, conflicts and heterodoxies of the sub-markets and the agents of the market, the metaphor would be precise. Moreover, the permanent and unbalanced dispute between distinct and asymmetrical capitals, owners and private agents disputes the ideals of converting metaphor into 'absolute truth', and imposes the spatial contingency of fleeting production of 'places as commodities'.

\section{ACKNOWLEDGEMENT}

Research developed at the doctoral level with the support of the Foundation for Research Support of the State of São Paulo (FAPESP) and the Lincoln Institute of Land Policy in the modality Postgraduate Student Fellow / Master's and PhD Thesis Support 2014 


\section{BIBLIOGRAPHIC REFERENCE}

ABRAMO, Pedro. Mercado e ordem urbana. Rio de Janeiro: Bertrand Brasil, 2001.

ABRAMO, Pedro. A cidade caleidoscópica. Rio de Janeiro: Bertrand Brasil, 2007.

ALFONSO, Oscar. La ciudad segmentada - una revisión de la síntesis espacial neoclásica. Revista de Economía Institucional, Bogotá, 2005, vol.7, n.13, pp. 159-191. Disponível em: http://www.economiainstitucional.com/pdf/No13/oalfonso13.pdf. Acessado em 19 de dez. de 2014.

AMORIM, Wagner Vinicius. A produção imobiliária e a reestruturação das cidades médias: Londrina e Maringá/PR. 2015. 413f. Tese (Doutorado em Geografia). Universidade Estadual Paulista, Presidente Prudente/SP.

AMORIM, Wagner Vinicius. A produção imobiliária e a reestruturação das cidades médias: Londrina e Maringá (PR). São Paulo: Cultura Acadêmica, 2017.

BOTELHO, Adriano. O urbano em fragmentos. São Paulo: Annablume; FAPESP, 2007.

CBIC - Câmara Brasileira da Indústria da Construção. PIB Brasil e Construção Civil. Informações sobre o PIB Brasil e da Construção Civil de acordo com os dados oficiais divulgados pelo IBGE. CBIC: Brasília, 2014a. Disponível em: http://www.cbicdados.com.br/menu/pib-e-investimento/pib-brasil-e-construcao-civil. Acessado em 27 de jan. de 2015.

CBIC - Câmara Brasileira da Indústria da Construção. Cadeia Produtiva. Estudos Específicos da Construção Civil. CBIC: Brasília, 2014b. Disponível em: http://www.cbicdados.com.br/menu/estudos-especificos-da-construcao-civil/cadeia-produtiva. Acessado em 31 de jan. de 2015.

CORDEIRO FILHO, Antonio. Empreendedorismo no Mercado Imobiliário Habitacional. São Paulo: Atlas, 2011.

FIX, Mariana. Financeirização e transformações recentes no circuito imobiliário no Brasil. 2011. $263 f$. Tese de Doutorado (Doutorado em Desenvolvimento Econômico), Instituto de Economia, Universidade Estadual de Campinas, 2011.

GOTTDIENER, Mark. A Produção Social do Espaço Urbano. (2a ed.). São Paulo: Edusp, 1997.

LEFEBVRE, Henri. Espaço e política. Belo Horizonte: Ed. UFMG, 2008.

LOGAN, John R.; MOLOTCH, Harvey L. Urban fortunes. The political economy of place. Los Angeles: University of California Press, 1987.

LOGAN, John R. La ciudad como máquina de crecimiento. In: Observatorio Metropolitano de Madrid (Ed.). EI mercado contra la ciudad. Globalización, gentrificación y políticas urbanas. Madrid: Traficantes de Sueños mapas, 2015, p. 157-210.

MARX, Karl. Produção, consumo, distribuição, troca [circulação]. In: Grundrisse. São Paulo: Boitempo, 2011 [1858], p. 7-64.

MELAZZO, Everaldo S. Mercado imobiliário, expansão territorial e transformações intra-urbanas: o caso de Presidente Prudente - SP. 1993. 144f. Dissertação de Mestrado. (Mestrado em Planejamento Urbano e Regional). Instituto de Pesquisa e Planejamento Urbano e Regional (IPPUR) da Universidade Federal do Rio de Janeiro, 1993.

MELAZZO, Everaldo S. Expansão Territorial e Estruturação do Espaço Urbano: Referências Teóricas. Cadernos do Departamento de Planejamento, UNESP - Presidente Prudente - SP, Nº 2, p. 37 a 46, 1997. MELAZZO, Everaldo S. Estratégias fundiárias e dinâmicas imobiliárias do capital financeirizado no Brasil dos anos 2000. Mercator, Fortaleza, V. 12, No Especial (2), 2013, p. 29-40. Disponível em: http://www. mercator.ufc.br/index.php/mercator/article/viewFile/1118/507. Acessado em 27 de jan. de 2015.

PEREIRA, Paulo C. X. Espaço, técnica e construção. São Paulo: Nobel, 1988.

PEREIRA, Paulo C. X. Negócios imobiliários e transformações sócio-territoriais em cidades latino-americanas: agentes, produtos e segregação. (Apresentação). In: PEREIRA, Paulo C. X. (org.). Negócios imobiliários e transformações sócio-territoriais em cidades da América Latina. São Paulo: FAUUSP, 2011. PEREIRA, Paulo C. X. Moinho satânico globalizado: imobiliário e ubiquidade financeira. In Anais do XIII Seminário Internacional da RII, VI Taller de Editores RIER. XII Seminário de la Red Iberoamericana 
de Investigadores sobre Globalización y Territorio (RII). Salvador/BA, 2014. Disponível em: http://www. rii.sei.ba.gov.br/anais_xiii/gt4/gt4_paulo.pdf. Acessado em 08 de jan. de 2015.

PEREIRA, Paulo C. X.; HIDALGO, R. (Orgs.). Producción inmobiliaria y reestructuración metropolitana en América Latina. Santiago do Chile: Alfabeta Artes Gráficas, 2008.

POLANYI, Karl. O mercado auto-regulável e as mercadorias fictícias: trabalho, terra e dinheiro. In: . A Grande Transformação. As origens de nossa época. $2^{a}$ ed. São Paulo: Ed. Campus, 2000 [1944], pp. 89-98. REBELO, Emília M. D. D. A. Mercado Imobiliário e Transformações Urbanas. (2002). 1344f. Tese (Doutorado em Engenharia Civil), Faculdade de Engenharia da Universidade do Porto. Disponível em: http://repositorio-aberto.up.pt/handle/10216/12977. Acessado em 12 de dez. de 2014.

SANDRONI, Paulo (org.). Novíssimo Dicionário de Economia. São Paulo: Ed. Best Seller, 1999.

SMOLKA, Martim. Para uma reflexão sobre o processo de estruturação interna das cidades brasileiras: o caso do Rio de Janeiro. Espaço e Debates, São Paulo, n. 21, 1987, pp. 39-50.

SOUZA, Genival E. Mercado imobiliário. Fatores que influenciam a decisão de compra de imóveis. São Paulo: Scortecci, 2012.

SPOSITO, Eliseu S. Produção e a Apropriação da Renda Fundiária Urbana em Presidente Prudente. (1990). 156f. Tese (Doutorado em Geografia Humana), Universidade de São Paulo.

SPOSITO, Maria E. B. O chão arranha o céu: a lógica da (re)produção monopolista da cidade. (1991). Tese de Doutorado (Doutorado em Geografia), Universidade de São Paulo, 1991.

TOPALOV, Christian. La urbanización capitalista. Mexico: Editorial Edicol Mexico, 1979. TOPALOV, Christian. Ganancias y rentas urbanas. Elementos teóricos. Madrid: Siglo XXI, 1984. 